\title{
Development and Validation of a Computer Education Curriculum Scale (CECS)
}

\author{
Kursat Arslan* \\ Computer Educatıon and Instructıonal Technology, Dokuz Eylul University, Izmir, Turkey
}

\section{Fatih Saltan}

Computer Education and Instructional Technology, Amasya University, Amasya, Turkey

\begin{tabular}{|c|c|}
\hline \multirow{2}{*}{$\begin{array}{l}\text { Article history } \\
\text { Received: } \\
28.07 .2015\end{array}$} & \multirow{7}{*}{$\begin{array}{l}\text { Primary school curriculum in Turkish educational system has } \\
\text { recently been revised based upon the basic principles of } \\
\text { constructivism. During this process, the role of teachers and } \\
\text { students, the teaching and learning processes, and the classroom } \\
\text { environment have been redefined. This study has been designed to } \\
\text { develop a Computer Education Curriculum Scale (CECS) in order } \\
\text { to assess attitudes of primary school teachers towards the new } \\
\text { curriculum and to determine and compare opinions of teachers on } \\
\text { the implementation and effectiveness of the new curriculum. For } \\
\text { this purpose, a 29-item Likert-type Computer Education } \\
\text { Curriculum Scale was developed and administrated to } 61 \text { teachers } \\
\text { working at primary schools from various cities of Turkey, who } \\
\text { voluntarily participated in the study. And all participants serve in } \\
\text { public schools, and have at least three years of experience as } \\
\text { computer education and technology teacher. For data collection } \\
\text { process, an online form of instrument was developed and collected } \\
\text { data from participants by sharing it through online forms. As a } \\
\text { result of statistical analyses on the survey data, } 5 \text { subscales were } \\
\text { determined. These subscales are named as recognition of the new } \\
\text { curriculum, course structure changes, identification of the teaching } \\
\text { environment, application of the new curriculum, and role and } \\
\text { contribution of teachers. Cronbach's alpha value of the whole } \\
\text { instrument is } 0.75 \text {. }\end{array}$} \\
\hline & \\
\hline & \\
\hline & \\
\hline 25.08. & \\
\hline Key words: & \\
\hline & \\
\hline
\end{tabular}

\section{Introduction}

Based on the principle of that high quality education depends on a high quality curriculum, the developments in the fields of science, technology, and human rights and demands of individuals should cause certain changes in curricula (Güleryüz, 2001). Those new developments should be integrated into curriculum improvement activities (Gözütok et all, 2005). Additionally, a new curriculum should be developed in the light of the realities and goals of the country to which it is applied and the needs and demands of individuals in the society (Gözütok, Akgün \& Karacaoğlu, 2005).Consequently, schools should be able to predict future trends (Gomleksiz, 2007).

\footnotetext{
Correspondence: kursata@gmail.com
} 
In Turkey, the compulsory primary education is eight years long. This process is both officially required and a right for every individual. This process is also very important because of the basic skills students gain during their primary education (Gürkan \& Gökçe,2002).

The Turkish National Education Ministry is in the process of expanding its educational programs nationwide and improving the quality of the national education system by utilizing $\$ 600$ million it has received from the World Bank. During this process, certain fundamental changes have been implemented in the educational system because of the European Union Integration Process. In 2004-2005 academic year, the new school curriculum was prepared and implemented at 120 schools in nine cities as a pilot project. The new curriculum is mainly based on a constructivist approach, student-centered learning, and thematic curriculum (Akbaba\&Altun, 2004). Furthermore, the individual differences principle of the multiple intelligence theory is another base of this new curriculum. Gözütok, Akgün, and Karacaoğlu (2004) reported that a curriculum relying on similar theoretical bases and sharing as many tasks of practice as possible may create a more successful teaching-learning process.

Currently, constructivism-based education system is being implemented in countries such as the USA, Taiwan, Spain, and New Zealand (Mathews, 2000). Fosnot and others state that constructivism is much more of a learning theory than a teaching style (Hoşgörür, 2002; Duman, 2004). It is also understood as a learning philosophy (Yeşilder, 2004). According to the constructivism theory, it is necessary for students to be active inside as well as outside of the classroom. This theory also states that individuals construct their own knowledge based on their past experiences. Therefore obtaining new knowledge is not only a result, but also a source to produce new knowledge (Akar \& Yildirim, 2004). In other words, the main function of learning for the learner is to make a connection between new understanding and an old one. During this process, the learner compares new knowledge to that previously held, then either accepts or refuses it (Cooperstein \& Kocevar-Weidinger, 2004). The participation of students in these processes, both physically and mentally, can be called the construction of knowledge (Deryakulu, 2001).

It is known that the constructivist learning approach requires a specific learning environment and in this approach the tasks and roles of teachers and students change in different ways. In addition, different types of assessment are needed to evaluate different types of individuals (Bukova \& Güğzel and Alkan , 2004).

The new primary school curriculum is based on the constructivism. Naturally, there are clear differences between the new and the old curricula. For example, cooperative learning is valued in the new curricula and this provides students an advantage of defined experiences through some hands-on activities. Multiple intelligence theory, project based instruction, problem based learning, learning by doing, learning by research, and cooperative learning are also emphasized in the new curriculum. To summarize, it is possible to say that in this process, both students and teachers have to be part of a collaboration in arranging learning environments and choosing activities, and students are encouraged to actively participate in teaching and learning activities.

Research studies show that the use of the constructivist approach can have great impact on students, and it yields students who are more motivated, more excited in the teaching and learning process, more able to apply science to real life situations, and more able to solve problems, than traditionally educated students. (Caprio, 1994; Baylor et al., 1997). 
There have been several studies on the new primary school curricula that give some clues about its effectiveness in practice. In a study by Gomleksiz (2005), teachers claimed that the new curriculum is effective at a mediocre level when analyzed in terms of city variable. Teachers also stated that they knew about, adapted, and implemented the new curriculum. In another study by Bukova-Güzel and Alkan (2005), teachers explained that there can be some difficulties in selecting activities in connection with the new teaching-learning environment. Again, in the same study, the students found the constructivist learning approach attractive for their learning. Researchers stated that teachers consider themselves as sufficient in the constructivist learning environment, but the observations of researchers show that they were not as adequate as they claimed to be.

Plotting curriculum and evaluating its results is an important point necessary to understand the gap between theory and practice. Determining the problems while implementing curriculum and developing solutions is the key stage of the curriculum. It can be said that every curriculum needs this stage. The real life results of the integration of theory and practice is important for determining the effectiveness of the curriculum. For that reason, determining the effectiveness of the new primary school computer curriculum based on the views of the teachers should be considered as a very important process. The main goal of this study is to develop a scale to obtain the opinions of teachers regarding the effectiveness of learning processes, teaching-learning activities, and content, and also to evaluate the new curriculum in terms of city, gender, education level, class level, and classroom size variables.

\section{Method}

\section{Population and Sample}

The population of the present study is all Computer Education and Instructional Technology teachers (ICT teacher) in Turkey. Convenience sampling was used to select the sample of this study. All participants in this study are volunteers and willing participants. The participants consisted of 61 teachers working at primary schools where the new computer education curriculum was implemented. The major characteristic of these teachers is that they are working as a computer education and technology teacher in their schools. The distribution of the teachers in the various cities is as follows: Ankara $(\mathrm{n}=17)$, Çanakkale $(\mathrm{n}=2)$, Elazı $\breve{g}(\mathrm{n}$ $=2), \operatorname{Erzurum}(\mathrm{n}=10)$, Eskişehir( $(\mathrm{n}=3), \operatorname{Istanbul}(\mathrm{n}=3), \operatorname{Izmir}(\mathrm{n}=4), \operatorname{Konya}(\mathrm{n}=4)$, Samsun(n = 5), Trabzon(3). Because several cities have only one participant, they are not given here and were named as "other". The number of valid questionnaires received from the teachers was 61. Other demographic information was listed in Table1.

Table 1. Demographic characteristics of the study population $(n=61)$.

\begin{tabular}{lll}
\hline & $\begin{array}{l}\text { Number of } \\
\text { students(n) }\end{array}$ & Percentage $(\%)$ \\
\hline University graduated & & \\
Anadolu University & 2 & 3.3 \\
Ankara University & 5 & 8.2 \\
Atatürk University & 11 & 18.0 \\
Ege University & 3 & 4.9 \\
Frrat University & 2 & 3.3 \\
Gazi University & 6 & 9.8 \\
Karadeniz Teknik University & 4 & 6.6 \\
Ondokuz University & 5 & 8.2 \\
Orta Doğu Teknik University & 5 & 8.2 \\
Selçuk University & 4 & 6.6 \\
\hline
\end{tabular}




\begin{tabular}{lll}
\hline Others & 12 & 19.2 \\
Gender & & \\
Male & 37 & 60.7 \\
$\quad$ Female & 24 & 39.3 \\
Level (grade) & 5 & 8.2 \\
$1-5$ & 7 & 11.5 \\
$1-8$ & 26 & 42.6 \\
$4-8$ & 16 & 26.2 \\
$6-8$ & 7 & 11.5 \\
Others & & \\
Undergraduate Program & 56 & 91.8 \\
$\quad$ Depertment of Computer Education and Instructional & 1.6 \\
Technology (CEIT) & 1 & 1.6 \\
$\quad$ Department of Classroom teacher & 1 & 4.9 \\
$\quad$ Department of Turkish Education & 3 & \\
$\quad$ Others & & \\
\hline
\end{tabular}

\section{Development of Data Collection Instrument}

The existing literature was analysed by determining related articles on the new curriculum in Turkey, selecting a few scales in order to define the sub-scale of instruments, and getting some questions for the item pool. In the second part, expert opinions were taken to finalize the instrument for pilot testing. In the last part, validity and reliability evidence was collected and determined.

\section{Analysis of Existing Literature}

Literature relevant to the new Turkish educational curriculum was selected from the ERIC database, the Google Scholar tool, and library resources using such key words as scales, curriculum, attitude, and also Turkish terms. Although there are many scales on the new curriculum in different areas such as mathematics and science, there was no single instrument targeting computer education and technology teachers. When developing the new instrument, the Physical Education Curriculum Analysis Tool (PECAT) (which is related to the quality of the physical education program was analyzed. A study of Gomleksiz $(2005,2007)$ about views of primary school teachers on the implementation and effectiveness of the new curriculum was also consulted. Generally, it is possible to say that the attitude of teachers in different areas about the new curriculum is positive. Gomleksiz (2005) defined factors for evaluating the effectiveness of the new primary school curriculum. Bukova-Güzel and Alkan (2005) investigated teachers' attitudes regarding the new curriculum. Yangin and Dindar (2005) used a questionnaire with 18 questions under two factors in a study about the perceptions of teachers regarding the new curriculum. These two factors were related to the aim of science and technology lesson and the activities related with to the lesson. The study of Turgut and Ari (2006) showed that although teachers perceived themselves as not having enough information about the new program or curriculum, they had a positive attitude toward the new curriculum. Also in this study, Turgut and Ari defined two factors like previous study.

\section{Taking Expert Opinion}

To test clarity and content validity, the first version of the instrument was submitted to a panel consisting of three specialists in the area of knowledge of the instrument, who were informed of the measures and concept. One of the specialists was a ICT teacher, another an expert on measurement and evaluation, and the last an expert on Turkish Education. These specialists evaluated every item for its distinctiveness, understandability, and appropriateness 
for the purpose. Essential changes were made in the statements based on their recommendations. These changes included both adding and omitting some items of the draft instrument, as well as fixing some grammar in many items. The tool finalized after adopting these changes. The feedback of experts was added at the end of the study.

\section{Cognitive Interviewing}

A cognitive interviewing procedure was used to define the problems about the items in the instrument. One ICT teacher was invited to this process. In this process, three steps were used; observation, listening, and direct questioning techniques. These techniques helped evaluate sources of response error in survey questionnaires (Wills, B. Gordon, 1999). In the observation process, some guiding questions were used, such as "where does he begin reading?" and "How long does he spend on each item and each part of instrument?" In the listening part, the participant was asked to share every thought and opinion while going through the instrument, but this part did not work as well during the interview because some participants preferred not to speak during this part of the interview. In the last part, direct questions were asked each participant in order to learn how to interpret the questions. After this process, a few items were revised with regard to clarity and understandability of items according to cognitive interviewing results. On the other hand, because of using an online form of the instrument, several changes could not be applied in the online form. Notes that were taken during this time were added at the end of the study.

\section{Type of the Scale}

The final form of the instrument consisted of 29-items using a five point Likert-type scale, where Complete $=5$, A lot $=4$, Medium $=3$, Very little $=2$, and Never $=1$.

\section{Content and Face Validity}

It is possible to organize validity studies into three groups -- item validity, sample validity, and face validity. For item validity, an instrument must be relevant to the intended content area, and for sampling validity, the instrument must reflect the total content area. For face validity, the format of the instrument is of main concern (Gay, et al, 2006). Content validity of the instruments with the 29 items and 5 points Likert-type was provided by obtaining opinions from three experts.

\section{Reliability of the Instrument}

It is possible to test reliability by using several types of reliability, each of which is a different kind of consistency (Fraenkal \& Wallen, 2005). Cronbach's Alpha Reliabilities were calculated to evaluate the homogeneity of the items in the pool.

\section{Data Collection Procedure}

It was not possible to collect date from teachers by going to their schools one by one. Rather, an online form of the instrument was developed in order to obtain data from the population. Some online forms that are frequently used by ICT teachers, such as Bote2003.com, Bilgisayarbilisim.com, were used in order to reach the potential target population. Respondents would complete the online version of the instruments. 


\section{Data Analysis Procedure}

First, a data cleaning process was performed. Data were screened by scanning for four basic criteria: lack or excess of data; outliers; strange patterns in distribution. As a result of this process, there are no missing data, outliers, or strange patterns in the distribution tables. Data were then analysed by means of factor analysis with varimax rotation.

\section{Results}

According to Stevens (1996), in order to determine the correct number of factors and to attain the best fitting structure, the following criteria can be used: eigenvalues higher than 1.0, factor loading higher than 0.30. Before conducting the factor analysis of responses, the Kaiser-Meyer Otkin (KMO) measure of sampling adequacy and Barlett's test was calculated to evaluate whether or not the sample was large enough to perform a satisfactory factor analysis. Barlett's Test was 902,426, $\mathrm{p}<0.001$. The calculated KMO was 0.549. In social science, the expected KMO value should be 0.60 or higher (George \& Mallery, 2001). On the other hand, Field (2000) pointed out that it is usually required that the KMO value be larger than 0.5. In addition, the KMO value of the scale is rather close the rule of 0.60. So for these reasons, this KMO value indicated that sample was adequate to perform a satisfactory factor analysis.

Before conducting factor analysis, bivariate correlation among items was inspected in order to judge factorial structure. The level of intercorrelation among all variables was low; therefore it was expected that one or more factors would be present.

To detect maximum variance for each factor, principal components analysis (PCA) with varimax rotation was performed on 31 items from ICT teachers for a sample of 37 males, and 24 females. As result of PCA, 11 factors were detected. On the other hand, when the Scree Plot test was performed, the number of factor was judged to be 5 as seen in Table2. A new PCA with varimax rotation was then conducted. Three items in the scale were removed because of their low factor loading values. The total number of items was decreased to 29 . As a result of this analysis, five factors best explain the factor structure of instrument. Six items in the scale made up $18.28 \%$ of the total variance on Factor 1. Five items made up $10.76 \%$ of the total variance on Factor 2. Four items in the scale made up $9.20 \%$ of the total variance on Factor 3. Eight items made up $8.51 \%$ of variance with Factor 4. The fifth factor is loaded with six items, and explains $7.27 \%$ of the total variance. These five factors explain a total variance of $54.63 \%$.

An analysis of the rotated factor analysis results (see Table 2) reveals the character for each of the five factors with respect to their items. The 14th , 4th, 30th, 3rd, 16th, and 27th items loaded on the first factor, which was named "Recognition of new curriculum". The 5th, 7th, 8th, 9th, and 2nd, loaded on the second factor, identified as "Current changes in lesson". The 18th, 17th, 11th, and 31st loaded on the third factor, the "Recognition of educational environment". The 23rd, 1st, 22nd, 25th, 15th, and 26th items loaded on the fourth factor, "Application of new curriculum". The 20th, 28th, 21st, 32nd, 12th, 13th, 6th, and 10th loaded on the fifth factor, "Teachers' role and contribution". These factors were named with reference to existing literature. 
Table 2. The results of Rotated factor analysis of scale; Mean, Standard deviations, Factor Loadings, and Communalities for CECS's items.

\begin{tabular}{|c|c|c|c|c|c|c|c|}
\hline \multirow[b]{2}{*}{ items } & \multirow[b]{2}{*}{$\mathrm{M}$} & \multirow[b]{2}{*}{ SD } & \multicolumn{5}{|c|}{ Factor Loadings } \\
\hline & & & 1 & 2 & 3 & 4 & 5 \\
\hline S14 & 2,45 & 0,72 & $\mathbf{0 , 8 5}$ & 0,24 & $-0,10$ & 0,01 & $-0,11$ \\
\hline S4 & 2,57 & 0,95 & 0,77 & 0,17 & 0,06 & 0,05 & $-0,13$ \\
\hline $\mathrm{S} 30$ & 2,67 & 0,86 & $\mathbf{0 , 7 3}$ & 0,11 & $-0,22$ & 0,02 & 0,11 \\
\hline $\mathrm{S} 3$ & 2,58 & 0,83 & 0,72 & 0,02 & 0,17 & 0,12 & 0,10 \\
\hline S16 & 2,30 & 0,65 & 0,66 & 0,33 & $-0,03$ & $-0,12$ & 0,16 \\
\hline S27 & 2,67 & 0,86 & $-0,42$ & $-0,01$ & $-0,19$ & 0,04 & $-0,19$ \\
\hline $\mathrm{S} 23$ & 2,87 & 0,95 & 0,20 & $\mathbf{0 , 8 2}$ & 0,18 & $-0,09$ & 0,13 \\
\hline S22 & 3,10 & 0,93 & 0,22 & 0,71 & 0,10 & $-0,08$ & 0,11 \\
\hline $\mathrm{S} 1$ & 2,68 & 0,97 & $-0,17$ & 0,70 & $-0,08$ & 0,12 & 0,01 \\
\hline S25 & 2,90 & 0,86 & 0,21 & 0,68 & 0,11 & 0,07 & 0,26 \\
\hline S15 & 2,45 & 0,70 & 0,31 & $\mathbf{0 , 5 5}$ & $-0,19$ & 0,21 & $-0,07$ \\
\hline S26 & 2,72 & 0,87 & 0,19 & 0,45 & $-0,07$ & 0,01 & 0,19 \\
\hline S5 & 4,03 & 0,99 & 0,05 & 0,18 & $\mathbf{0 , 8 6}$ & $-0,07$ & $-0,01$ \\
\hline S7 & 3,77 & 1,20 & $-0,09$ & $-0,05$ & $\mathbf{0 , 8 1}$ & 0,06 & 0,05 \\
\hline S8 & 3,80 & 0,95 & 0,10 & 0,05 & $\mathbf{0 , 7 7}$ & 0,08 & 0,00 \\
\hline S9 & 2,72 & 0,80 & 0,39 & $-0,13$ & 0,46 & 0,28 & 0,18 \\
\hline S2 & 3,02 & 1,32 & $-0,05$ & $-0,07$ & $\mathbf{0 , 4 2}$ & $-0,07$ & 0,24 \\
\hline $\mathrm{S} 18$ & 3,70 & 1,08 & $-0,04$ & 0,27 & $-0,16$ & $\mathbf{0 , 7 9}$ & $-0,27$ \\
\hline S17 & 3,72 & 1,14 & 0,04 & 0,17 & 0,07 & 0,78 & $-0,28$ \\
\hline S11 & 2,52 & 1,24 & $-0,04$ & $-0,18$ & 0,10 & 0,74 & 0,27 \\
\hline S31 & 2,53 & 1,08 & 0,07 & $-0,04$ & 0,06 & 0,74 & 0,31 \\
\hline S20 & 1,77 & 0,70 & 0,10 & 0,19 & 0,24 & $-0,04$ & 0,65 \\
\hline S28 & 2,42 & 0,65 & $-0,35$ & $-0,14$ & $-0,07$ & 0,09 & $-0,56$ \\
\hline $\mathrm{S} 21$ & 2,08 & 0,62 & 0,02 & 0,26 & $-0,05$ & $-0,01$ & $\mathbf{0 , 5 0}$ \\
\hline S32 & 2,67 & 1,08 & $-0,02$ & 0,16 & 0,22 & 0,25 & $\mathbf{0 , 5 0}$ \\
\hline $\mathrm{S} 12$ & 3,25 & 0,95 & $-0,14$ & 0,35 & 0,37 & 0,17 & $-0,41$ \\
\hline $\mathrm{S} 13$ & 3,42 & 1,05 & 0,33 & $-0,02$ & $-0,07$ & 0,38 & $\mathbf{0 , 4 0}$ \\
\hline S6 & 4,32 & 0,98 & 0,19 & 0,33 & 0,29 & $-0,13$ & $-0,40$ \\
\hline $\mathrm{S} 10$ & 2,80 & 1,23 & $-0,29$ & 0,29 & 0,20 & 0,15 & $\mathbf{0 , 3 5}$ \\
\hline
\end{tabular}

Note: boldfaces indicates highest factor loading. Description of items found in Appendix A. factor 1 = Recognition of new curriculum; factor $2=$ Current changes in lesson; Factor $3=$ Recognition of educational environment; factor 5 = Teachers' role and contribution; Factor 4 $=$ Application of new curriculum.

The alpha internal consistency coefficient that was calculated for the reliability of the scale of attitudes towards new computer education curriculum was found to be 0.75 . In addition, for each factor, the alpha value was calculated. The alpha value for the first factor was 0.80 ; for second 0.71 , for the third 0.77 , for the fourth 0.80 , and for the fifth 0.30 . Numbers of items and Cronbach's alpha value for each item are given in Table 3. 
Table 3. Cronbach alpha values for each subscale.

\begin{tabular}{lll}
\hline Scale & Number of item & Cronbach alpha $(\alpha)$ \\
\hline Recognition of new curriculum & 6 & .80 \\
Current changes in lesson & 5 & .67 \\
Recognition of educational environment & 4 & .77 \\
Application of new curriculum & 6 & .80 \\
Teachers' role and contribution & 8 & .35 \\
\hline Total & 29 & .75 \\
\hline
\end{tabular}

\section{Discussion and Conclusion}

The data of the study were collected using the new Computer Education Curriculum Scale (CECS) developed by the author. The five-point Likert type scale consisted of 31 items asking the teachers to rate their ideas about the CECS. Principal component analysis was performed. The KMO value of the scale was calculated as 0.55, and Bartlett's test was measured as $902,426(\mathrm{p}<0.00)$. According to an analysis of results, five sub-scales were identified in the instrument. The sub-scales were named as Recognition of new curriculum, Current changes in lesson, Recognition of educational environment, Application of new curriculum, and Teachers' role and contribution, respectively. Cronbach's alpha reliability coefficient of whole instrument was measured to be 0.75 . Cronbach's alpha reliability coefficient calculated for the four sub-scales varied between 0.35 and 0.80 . According to factor analysis, the instrument explained $54.63 \%$ of the total variance. The percentage of explained variance is sufficient for interpreting the factor structure of this instrument.

For validity studies, content and face validity, and construct validity were examined. For reliability, the Cronbach alpha reliability coefficient was calculated. According to results from factor analysis, the CECS was found to be valid and reliable. Data obtained from this instrument will give detailed information from teachers about the new computer education curriculum. In light of this information, problematic issues of the curriculum can be revised.

The calculated KMO was 0.55 indicating that the sample was not large enough to perform satisfactory factor analysis for social science. On the other hand, it has been reported that for KMO when statistical information is between 0.90 and 1.00 , the sample can be considered excellent, between 0.80 and 0.89 very good, between 0.70 and 0.79 good, between 0.60 and 0.69 average, between 0.50 and 0.59 weak, and when less than 0.50 it is not acceptable. In this study the KMO was 0.55 , which showed that the size of the sample was weak. This KMO value is probably explained by the smaller sample size.

As a conclusion, A 29-item Likert-type Computer Education Curriculum scale was developed. The reliability of the scale as tested by Cronbach's alpha was 0.75 . The scale includes five subscales. In further studies, a larger sample size would be helpful in overcoming some limitations of the present study.

\section{References}

Akbaba-Altun, S. (2004). Information Technology Classrooms and Elementary School Principals' Roles: Turkish Experience. Education and Information Technologies, Vol. 9 (3), 255-270.

Akbaba-Altun, S. (2006). Complexity of Integrating Computer Technologies into Education in Turkey. Educational Technology \& Society, Vol. 9 (1), 176-187+ 
Akkoyunlu, B. (2002). Educational Technology in Turkey: Past, Present and Future. Education Media International, Vol. 39 (2), 165-174.

Bukova-Güzel, E. \& Aklan, H. (2005). Yeniden yapılandırılan ilkögretim programı pilot uygulamasinin degerlendirilmesi [An evaluation of the pilot program of primary program reconfigured]. Educational Sciences: Theory \& Practice,5, 385-420.

Caprio, M. W. (1994). Easing into constructivism, connecting meaningful learning with student experience. Journal of College Science Teaching, 23, 210-212.

Coşkun, E. (2005). İlköğretim dördüncü ve beşinci sınıf öğretmen ve öğrencilerinin yeni Türkçe dersi ögretim programı’yla ilgili görüşleri üzerine nitel bir araştırma [Perceptions of elementary school teachers and students regarding new Turkish program: a qualitative study]. Educational Sciences: Theory \& Practice, 5 (2), 421 476.

Deryakulu, D. (2001). Yapıcı öğrenme [constructive learning]. Ankara: Eğitim Sen Yayınları.

Duman, B. (2004). Öğrenme-ögretme kuramları ve süreç temelli ögretim [Learning and teaching theory and process-based teaching]. Ankara: An1 Pub.

George, D. \& Mallery, P. (2001). SPSS for Windows; Step by step. Allyn \& Bacon, The United States of America.

Gömleksiz M. N. (2005). Yeni ilköğretim programının uygulamadaki etkililiğinin değerlendirilmesi [evaluation of effectiveness of new primary school curriculum]. Educational Sciences: Theory \& Practice, 5 (2), 339-384.

Gömleksiz, M. N. ve Kan, A. Ü. (2006). Yeni sosyal bilgiler dersi öğretim programının eleștirel ve yaratıcı düşünme becerilerini kazandırmadaki etkililiğinin belirlenmesi (Diyarbakır ili örneği) [defining effectiveness of new curriculum of social studies in gaining critical and creative thinking skills]. 15. National Educational Scinece Conference. 13-15 September 2006, Muğla Univ., Muğla.

Gözütok, F. D., Akgün, Ö. E. ve Karacaoğlu, Ö. C. (2005). İlköğretim programlarının öğretmen yeterlilikleri açısından değerlendirilmesi [evaluation of primary school curriculum in terms of teacher qualifications]. Eğitimde Yansımalar: VIII Yeni İlköğretim Programlarını Değerlendirme Sempozyumu bildirileri kitabı içinde (s.1740). Ankara: Sim Matbaas1. 82 Eurasian Journal of Educational Research

Güleryüz, H. (2001). Eğitim programlarının dili ve yaratici öğrenme [language of education programs and creative learning]. Ankara: PegemA Pub

Gülpınar, M. A. (2005). Beyin/zihin temelli öğrenme ilkeleri ve eğitimde yapılandırmacı modeller [brain based learning principles and constructivist models in education]. Educational Sciences: Theory \& Practice, 5 (2), 271-306.

Holloway, J. H. (1999). Caution: constructivism ahead. Educational Leadership, 57(3), 85-86.

Hoşlgörür, V. (2002). Sınıf yönetiminde yapısalcı yaklaşım [constructivist approach in classroom management]. Journal of educational Research, 9, 73-78.

Howe, K. R.\& Berv, J. (2000). Constructing constructivism, epistemological and pedagogical. In D. C. Phillips (Ed.), Constructivism in Education: Opinions and Second Opinions on Constroversial Issues (pp.19-40). Chicago, Illlinois:The University of Chicago Press.

MEB. (1998). İlköğretim Okulları Seçmeli Bilgisayar Dersi 1-2-3-4-5 Öğretim Program1. [Elementary School 1-2-3-4-5 Elective Computer Education Courses Program.] Eylül 2492 Sayılı Tebliğler Dergisi.

Özbay, Funda (2007). EKU University Web Page, Science of Education. http://www2.aku.edu.tr/ gocak/2007dersnot/egitimbilimleri/apa.pdf . Accessed 17 January 2010 
Özdemir, M. S. (2005). İlköğretim okullarındaki öğretmenlerin yeni ilköğretim programlarına (IV. Sınıflar) ilişkin görüşleri [perceptions of primary school teachers about new primary education curriculum]. XIV National Educational Scinece Conference. Proceeding book (s.573-581), Pamukkale Univ., Denizli.

Özkan, B. (2001). Yapılandırmacı ögrenme ortamlarında özgün etkinlik ve materyal kullanımının etkililiği [effectiveness of using original activities and materials in constructivist learning environment].YUnpublished PhD Thesis, Hacettepe Univ., Ankara.

Stevens, J., (1996). Applied Multivariate Statistics for the Social Sciences, third ed. Lawrence Elbaum Associates, USA, pp. 363-428.

Willis, B. G. (1999). Cognitive Interviewing A "how to" guide. http://appliedresearch. cancer.gov/areas /cognitive/interview.pdf. Accessed 25 June 2010 